\title{
Gender roles and women's mental health: their influence on the demand for psychological care
}

\author{
Sandra Toribio-Caballero ${ }^{1,}{ }^{*}$, Violeta Cardenal $^{2}$, Alejandro Ávila ${ }^{2}$, and Mercedes Ovejero ${ }^{2}$ \\ 1 Instituto de Psicoterapia Relacional. Madrid (Spain) \\ 2 Facultad de Psicologia, Universidad Complutense de Madrid (Spain)
}

\begin{abstract}
Título: Roles de género y salud mental en las mujeres: su influencia en la demanda de atención psicológica.

Resumen: La prevalencia de determinados diagnósticos -trastorno de la conducta alimentaria, depresión, ansiedad y trastorno límite- es superior en mujeres que en hombres. Considerando la salud mental en mujeres, resulta imprescindible poner el foco en los aspectos sociales que influyen en la forma de enfermar. Se estudia en una muestra de 368 mujeres la capacidad de clasificación de algunas variables clínicas y factores socioculturales (conformidad con las normas de género) para determinar si una mujer está recibiendo asistencia psicológica o no, así como la importancia de cada una de esas variables a la hora de pronosticar qué mujeres estarían recibiendo terapia. Los resultados mostraron que cuando las mujeres puntúan alto en al gunas variables clínicas (como Ideaciones Suicidas y Rasgos Límites) y en algunas relacionadas con conformidad con las normas de género (Cuidadora de Niños/as, Agradable en las relaciones y la Fidelidad Sexual) era más probable que estén recibiendo tratamiento psicológico. Por lo tanto, se considera que la inclusión de la perspectiva de género en programas de educativos, de salud y atención psicológica es fundamental para que los roles de género puedan ser más diversos y constriñan menos las potencialidades de las personas, lo que influirá en que tengan una mejor salud.

Palabras clave: Conformidad con los roles de género. Trastornos psicológicos en mujeres. Trastornos conducta alimentaria. Depresión. Ansiedad. Trastorno límite de la personalidad.
\end{abstract}

\section{Introduction}

Women's health is different from men's health. Women have poorer overall health: they have a higher number of chronic conditions, higher levels of cognitive impairment, and a higher prevalence of severe pain and physical disability (Case \& Paxson, 2005; Chiasson \& Hirsch, 2005; Crimmins et al., 2010; Ministerio de Sanidad, Consumo y Bienestar Social [Spanish Ministry of Health, Consumer Affairs, and Social Welfare], 2018a; Oksuzyan et al., 2019; Sánchez-López et al., 2012). However, if there is one area of health where gender-based differences in the prevalence of disorders is particularly significant, that is mental health, where the prevalence of mental health problems is twice as high in women as in men (Ministerio de Sanidad, Consumo y Bienestar Social [Spanish Ministry of Health, Consumer Affairs, and Social Welfare], 2018b; World Health Organisation [WHO], 2018a; Velasco et al., 2007). In fact, even though women have a longer life expectancy, engage in a greater number of preventive behaviours, and have fewer addictions, they paradoxically have poorer health, wellbeing, and quality of life than men. They also use more health services and psycho-

* Correspondence address [Dirección para correspondencia]

Sandra Toribio-Caballero. Instituto de Psicoterapia Relacional, C/ Alberto Aguilera, 10, $1^{\circ}$ Izquierda, 28015 Madrid (Spain).

Email: sandratoribio@psicoterapiarelacional.com

(Article received: 13-10-2020, revised: 8-3-2021, accepted: 11-4-2021)

\begin{abstract}
The prevalence of certain diagnoses, such as eating disorders, depression, anxiety, and borderline personality disorder, is higher among women than among men. When it comes to women's mental health, focusing on social aspects influencing the way women fall ill becomes crucial. Using a sample of 368 women, we studied the classification ability of a number of clinical variables and sociocultural factors (conformity to gender norms) in order to ascertain whether or not women were receiving psychological care and determine the importance of each of the variables when predicting which women were receiving therapy. Our results showed that women were more likely to be receiving psychological treatment when scoring high on certain clinical variables (such as Suicidal Ideation and Borderline Features) and on a number of variables related to conforming to gender norms (Care for Children, Nice in Relationships, and Sexual Fidelity). Therefore, we believe that integrating the gender perspective into educational, health-related, and psychological care programmes is essential so that gender roles can become more diverse and less constricting of people's potential, resulting in improved health.

Keywords: Gender role conformity. Psychological disorders in women. Eating disorders. Depression. Anxiety. Borderline personality disorder.
\end{abstract}

tropic drugs and have a higher prevalence of numerous psychiatric disorders (Hartung \& Lefler, 2019; Leal, 2006). This has been termed "the mortality/morbidity paradox": women live longer than men but are in poorer health (Case \& Paxson, 2005; Sánchez-López \& Limiñana, 2017).

Epidemiological data show that there are a number of diagnoses for which there are no sex-based differences, e.g. the prevalence of schizophrenia is very similar in men and women (Jiménez \& Vázquez, 2012; Sáenz-Herrero, 2015). The prevalence of other diagnoses, such as antisocial, narcissistic, obsessive-compulsive, paranoid, schizotypal, and schizoid personality disorders, is higher in men (Garnica de Cos, 2015). Men also commit suicide at a higher rate than women (Mackenzie et al., 2019) and tend to use more violent means to do so (Bahamón et al., 2019; Kohen, 2010).

However, there are many other disorders that are much more prevalent in women than in men. The most significant example is eating disorders, with the highest female-to-male ratio of all psychiatric disorders (Fletcher-Janzen, 2009; Keel \& Forney, 2013): 90\% of all people diagnosed are women (Kohen, 2010; Ruiz et al., 2016). A similar situation applies to affective disorders. Depression is two to three times more common in women than in men (Ferrari et al., 2013; Pérez \& Serra, 1997; Pérez \& Gaviña, 2015; Sáenz-Herrero, 2015; Salk et al., 2017); rates of bipolar disorder are similar in both sexes, but women's cycles are faster and experience a greater number of depressive episodes and mixed phases. Anxiety 
disorders (such as panic disorder, specific phobias, and generalised anxiety disorder) and dysthymia affect women more than men (Bekker \& van Mens-Verhulst, 2007; Leal, 2006; Pérez \& Gaviña, 2015; Sánchez-López \& Cuéllar, 2013). With regard to personality disorders, epidemiological data show that women have a higher prevalence rate of borderline personality disorder than men (3:1) (Escribano, 2006; García et al., 2010; Kienast et al., 2014; Ortiz-Tallo et al., 2011; Skodol \& Bernder, 2003; Tomko et al., 2014; Trull et al., 2010).

It also follows from the above that women have, in general, a higher prevalence of internalising disorders (anxiety, depression) while men tend towards externalising disorders (antisocial personality disorder, addictions) (Eaton et al., 2012).

The sex differential in morbidity may be explained by two hypotheses. The first hypothesis holds that constitutional, genetic, and/or endocrine factors are determinants of sexbased differences in morbidity. However, it seems that most studies in this area fall short in explaining this phenomenon (Fine, 2018; Montero et al., 2004; Pérez \& Serra, 1997). As pointed out by Sánchez-López and Cuéllar (2013) echoing Ellis et al. (2008), mental disorders in childhood-e.g., conduct disorders such as attention deficit hyperactivity disorder (Arnett et al., 2015), communication and language disorders such as stuttering, autism (Baron-Cohen et al., 2011), and Asperger syndrome-are more commonly diagnosed in boys versus girls. The trend reverses in adolescence, where females start to have poorer health. Data suggest that these are not (only) genetic disorders but may also be influenced by environmental factors.

The second hypothesis is based on environmental theories, which argue that sociocultural variables acting through socially imposed roles and patterns of behaviour are what ultimately condition the way in which men and women manifest their psychological distress (Montero et al., 2004; Sánchez-López et al., 2013). This is in line with Kohen (2010), who, quoting Dohrenwend and Dohrenwend (1977), Gove (1984), and Nazroo (2001), point out that women's mental health being poorer than men's may be related to women being affected differently by social stress: they usually are poorer than men-which has been termed the feminisation of poverty (Belle \& Doucet, 2003)-and experience more abuse (sexual abuse and sexist violence) than men during both childhood and adulthood (WHO, 2018a). Genderbased violence, the sexual division of labour, women's double or triple shifts (work, housework/caregiving, and affective networks), and beauty ideals (social pressure on their bodies) are other significant contributors to women's poorer health (Sánchez, 2018).

As Wood and Eagly (2013) pointed out, it is true that neither biology nor culture alone can explain sex-based differences or similarities. This is where the biopsychosocial model (Engel, 1980) becomes particularly relevant as an explanatory theory, as it is widely accepted and used for conceptualising and treating a wide range of physical and mental health problems (Meyer \& Melchert, 2011) and is still very popular today (Bott et al., 2016; Yagahmaian \& MillerSmedema, 2019).

Sex and gender are two complex and distinct entities, although they may overlap and relate to each other to some extent (Fernández, 2004): gender interacts with biological sex, but it is a different concept (WHO, 2019). However, in the scientific literature, the two terms are often used interchangeably and confusingly (Sánchez-López \& Limiñana, 2017). The term sex refers to biologically determined characteristics (chromosomes, genes, gonads, hormones, morphology, etc.), while the term gender refers to the socially defined roles, characteristics, and opportunities that are considered appropriate for men, women, boys, girls, and individuals with non-binary identities (WHO, 2019).

These roles and characteristics are learnt through the process of differential socialisation, which begins at birth and continues throughout life, whereby individuals, through interaction, learn and internalise the values, attitudes, expectations, and behaviours characteristic of the society to which they belong, enabling them to function in it (Giddens, 2014). The World Health Organisation (2019) states that if people do not conform to norms or roles (including masculinity and femininity), they are often subject to stigmatisation, social exclusion, and discrimination, which may eventually have a negative impact on their health.

Based on the above, we set out to analyse to what extent gender (sociocultural aspects) contributes to women seeking psychological care. Our objective was to study the classification ability of a number of clinical variables-taking as a reference the classification of the Diagnostic and Statistical Manual of Mental Disorders or DSM-5 by the American Psychiatric Association (2013)-and sociocultural factors (conformity to gender norms) in order to ascertain whether or not women were receiving psychological care and determine the importance of each of the variables when predicting which women were receiving therapy.

\section{Method}

\section{Design}

This study used a retrospective, cross-sectional, ex post facto group comparison design. In ex post facto designs, a sample of participants with already existing qualities associated with the study variables is selected. The potential independent variables are provided, and the dependent variable can be observed before, after, or at the same time as the independent variable (as it is the case of the present study). This is a retrospective group comparison because the study compares a group of women selected for having a certain characteristic (i.e. the clinical cases) with another group of women lacking that characteristic (the non-clinical cases). The groups are compared on a number of potential independent variables (conformity to feminine/masculine gender 
norms and clinical variables), which are considered relevant for the occurrence of that characteristic.

\section{Participants}

The total sample consisted of 368 women, but 10 of the assessments were discarded due to missing data. The final sample was made up of 358 women $(M=38.41, S D=$ 12.96), $168(M=35.75, S D=11.49)$ of whom were recruited from private psychological care centres and were receiving psychological and/or psychiatric care, and 190 ( $M=$
40.73, SD $=13.73$ ) were controls, as they were not receiving psychological/psychiatric care.

The inclusion criteria were as follows: (a) being a cisgender woman, (b) being over 18 years old, (c) being proficient and fluent in Spanish, and (d) not being institutionalised. The exclusion criteria were (a) being a man, (b) being a transgender/transsexual woman, (c) being under 18 years of age, (d) having language comprehension problems for whatever reason (difficulties in understanding questionnaires, intellectual disability, etc.), and (e) being institutionalised.

Table 1 shows the relevant sociodemographic information.

Table 1

Descriptive analysis of sociodemographic variables.

\begin{tabular}{|c|c|c|c|c|c|c|c|c|c|}
\hline & \multirow{2}{*}{ Variable } & \multicolumn{2}{|c|}{ Non-clinical } & \multicolumn{2}{|c|}{ Clinical } & \multirow{2}{*}{$\chi^{2}$} & \multirow{2}{*}{$d f$} & \multirow[b]{2}{*}{$p$} & \multirow{2}{*}{$V$} \\
\hline & & $N$ & $\%$ & $N$ & $\%$ & & & & \\
\hline \multirow{3}{*}{$\begin{array}{l}\text { Level of } \\
\text { Education }\end{array}$} & Primary/Secondary Education & 29 & 15.26 & 37 & 17.79 & \multirow{3}{*}{.460} & \multirow{3}{*}{2} & \multirow{3}{*}{.794} & \multirow{3}{*}{-} \\
\hline & Vocational Training & 21 & 11.05 & 22 & 13.10 & & & & \\
\hline & University & 140 & 73.68 & 149 & 71.63 & & & & \\
\hline & Employed & 140 & 73.68 & 111 & 66.07 & \multirow{5}{*}{4.514} & \multirow{5}{*}{4} & \multirow{5}{*}{.341} & \multirow{5}{*}{.112} \\
\hline Academic/ & On leave & 4 & 2.11 & 4 & 2.38 & & & & \\
\hline Employment & Household chores & 8 & 4.21 & 5 & 2.98 & & & & \\
\hline \multirow[t]{2}{*}{ Status } & Student & 18 & 9.47 & 25 & 14.88 & & & & \\
\hline & Retired & 6 & 3.16 & 1 & .60 & & & & \\
\hline \multirow{8}{*}{ Marital Status } & With a partner & 133 & 70.00 & 85 & 50.60 & \multirow{5}{*}{17.067} & \multirow{5}{*}{4} & \multirow{5}{*}{.002} & \multirow{5}{*}{.193} \\
\hline & Separated/Divorced & 9 & 4.73 & 15 & 8.93 & & & & \\
\hline & Single & 40 & 21.05 & 60 & 35.71 & & & & \\
\hline & Widow & 5 & 2.63 & 2 & 1.19 & & & & \\
\hline & \multirow[t]{3}{*}{ Other } & 3 & 1.58 & 6 & 3.57 & & & & \\
\hline & & \multicolumn{2}{|c|}{ Non-clinical } & \multicolumn{2}{|c|}{ Clinical } & & & & \\
\hline & & $M$ & $S D$ & $M$ & $S D$ & $t$ & $d f$ & $p$ & $d$ \\
\hline & Age & 40.73 & 13,73 & 35.75 & 11.49 & 3.73 & 353.37 & $<.001$ & .391 \\
\hline
\end{tabular}

Note. M: Mean. SD: Standard deviation. df: Degrees of freedom. V: Cramer's V. d: effect size (Cohen's $d$ ). For the age variable, Welch's correction is applied after verifying the statistical significance of Levene's test.

The main reasons for consultation in the clinical group are related to anxiety problems (39.29\%), followed by couple relationship problems (27.98\%) and depression (27.38\%). None of the women in the clinical group reported alcohol or drug problems as a reason for consultation.

Table 2 shows the reasons for consultation in the clinical group.

\section{Instruments}

The assessment instruments collected sociodemographic information and data on clinical variables and conformity to gender norms.

An ad hoc sociodemographic questionnaire was included to collect information on age, sex, level of education, employment status, and marital status. The therapists of the women who participated in the study completed a screening questionnaire indicating the type of centre they worked in (public practice, private practice, specialised centre), reasons for consultation-up to three reasons for consultation ranging from 1 (major) to 3 (minor)-, and type of diagnosis (clinical syndromes based on the DSM-5).
Table 2

Reasons for consultation in the clinical group.

\begin{tabular}{llc}
\multicolumn{1}{c}{ Reasons for consultation } & $\mathrm{N}$ & $\%$ \\
\hline Anxiety problems & 66 & 39.29 \\
Couple relationship problems & 47 & 27.98 \\
Depression & 46 & 27.38 \\
Insecurity & 41 & 24.40 \\
Family problems & 36 & 21.43 \\
Difficulties in social relations & 28 & 16.67 \\
Loneliness & 19 & 11.31 \\
Obsessions & 17 & 10.12 \\
Work stress & 10 & 5.95 \\
Tiredness / Illness & 9 & 5.36 \\
Others & 7 & 4.17 \\
Sexual disorders & 6 & 3.57 \\
Disruptive / Antisocial behaviour & 1 & 0.60 \\
Employment / Study problems & 1 & 0.60 \\
Alcohol abuse & 0 & 0.00 \\
Drug abuse & 0 & 0.00 \\
\hline Note Some women have more than one reason
\end{tabular}

Note. Some women have more than one reason for consultation.

The validated Spanish version of the Personality Assessment Inventory (PAI) was used (Morey, 2007). The Spanish adaptation of the shortened scale (165 items) was validated 
by Ortiz-Tallo et al. (2015). Each item had four response options: False, not true at all (F), Slightly true (ST), Mainly true (MT), and Very true (VT). It comprehensively assesses adult psychopathology using 22 scales (Ortiz-Tallo et al., 2011): 4 validity scales (Inconsistency, Infrequency, Negative Impression, and Positive Impression), 11 clinical scales (Somatic Concerns, Anxiety, Anxiety-Related Disorders, Depression, Mania, Paranoia, Schizophrenia, Borderline Features, Antisocial Features, Alcohol Problems, and Drug Problems), 5 treatment consideration scales (Aggression, Suicidal ideation, Stress, Nonsupport, and Treatment rejection), and 2 interpersonal scales (Dominance and Warmth). Regarding the level of reliability of the short form, its mean internal consistency/alpha coefficient was 0.74 in normal samples and 0.81 in clinical samples. The mean test-retest reliability, understood as temporal consistency, was 0.82 . The mean correlation value between the short and full forms was 0.90 in normal samples and 0.93 in clinical samples, suggesting that the short form yields scores reasonably close to the scores individuals would obtain using the full form of the questionnaire (Ortiz-Tallo et al., 2011).

Since the PAI does not measure eating disorders, the Eating Attitudes Test (EAT-26) was included. This 26-item version was developed by Garner et al. (1982) from the full form EAT-40 (Garner \& Garfinkel, 1979). Each item uses a Likert scale with 6 response options: never $(0)$, rarely $(0)$, sometimes (0), often (1), usually (2), and always (3). Total scores range from 0 to 78 . The EAT-26 consists of three scales or factors (Garandillas et al., 2003): the Diet Scale (attention to calories ingested and burnt doing physical exercise, desire to be thin, sense of guilt after eating), Bulimia Factor (scale of bulimia and concern about food), and Oral Control (items describing food intake mode and its control). As pointed out by Garandillas et al. (2003), the EAT-26 and the EAT-40 are highly correlated $(r=.98)$, suggesting that the shortened version retains adequate reliability and validity properties for detecting eating disorders (Pike et al., 2008; Garfinkel \& Newman, 2001). The level of reliability and internal consistency of the test as measured with Cronbach's alpha was excellent $(>$.90) (Rivas et al., 2010).

The Conformity to Feminine Norms Inventory (CFNI) was also included (Mahalik et al., 2005). It assesses women's conformity to a set of dominant feminine norms in American culture. Femininity is understood as the degree of conformity (emotional, cognitive, and/or behavioural) to a set of gender norms that are considered socially appropriate for women in terms of behaviours, attitudes, feelings, and thoughts transmitted by each culture with which members of each society can identify to a greater or lesser extent (Sánchez-López \& Limiñana, 2017). The Spanish adaptation of the test was carried out by Sánchez-López et al. (2009). Reliability data (an alpha coefficient of .87 for the total scale) confirmed the validity of the CFNI for use in the Spanish population. The CFNI consists of 84 items rated on a 4point scale $(0=$ Strongly disagree, $1=$ Disagree, $2=$ Agree, 3 = Strongly agree). It can be administered both individually and collectively to individuals over 18 years of age. The duration of the questionnaire ranges between 15 and 20 minutes. Total scores range from 0 to 252 points. Higher scores indicate higher satisfaction with the traditional role of women. The factors that make up the CFNI are the following: Nice in relationships (developing friendly and supportive relationships with others), Care for Children (taking care of and being with children), Thinness (pursuing a thin body ideal), Sexual Fidelity (keeping sexual intimacy contained within one committed relationship), Modesty (refraining from calling attention to one's talents or abilities), Romantic relationship (investing self in romantic relationship), Domestic (maintaining the home), and Invest in appearance (committing resources to maintaining and improving physical appearance) (Mahalik et al., 2005).

The Conformity to Masculine Norms Inventory (CMNI) was also included (Mahalik et al., 2003). It assesses conformity to a set of dominant masculine norms in US culture. Its Spanish adaptation was conducted by Cuéllar-Flores et al. (2011). Reliability data (an alpha coefficient of .90 for the total scale) confirmed the validity of the CMNI for use in the Spanish population. It consists of 94 items rated on a 4 point scale $(0=$ Strongly disagree, $1=$ Disagree, $2=$ Agree, 3 = Strongly agree). The factors making up the CMNI are related to attitudes, beliefs, and behaviours reflecting conformity or non-conformity to eleven normative messages associated with masculine gender roles: Winning, Emotional Control, Risk-Taking, Violence, Dominance, Playboy, SelfReliance, Primacy of Work, Power Over Women, Disdain for Homosexuals, Physical Toughness, and Pursuit of Status (Cuéllar-Flores et al., 2011).

Reliability data for the scores of each scale obtained in the present study are provided in the Results section.

\section{Procedure}

Twenty-seven psychotherapists from different provinces of Spain (Madrid, Valencia, and Barcelona) and three psychotherapy centres participated in the recruitment of the sample. Participants in the control group (women who were not receiving psychological/psychiatric care at the time) were recruited using a snowball sampling procedure. Participation in the study was voluntary. Informed consent was included on the first page of the booklet where the different instruments used were compiled. The booklets were handdelivered and did not need to be filled in on the spot. In most cases, the contact persons gave the questionnaires to the women, who returned them to the same contact person. In one of the collaborating centres, the questionnaires were filled in collectively.

\section{Data analysis}

After excluding the participants who failed to meet the aforementioned inclusion criteria, all gender variables and EAT scores were standardised using T-scores, the same scoring system used by the PAI. T-scores use a scale derived from Z-scores and are calculated by transforming the Z- 
score for each participant on each scale, multiplying it by 10 , and adding 50 points. This results in variables whose mean would be equal to 50 and their standard deviation would be equal to 10. After standardisation of the variables, a descriptive study of each independent variable for each study group was carried out. Statistics of central tendency, variability, and shape of the distribution were included.

The aim of this study was to explore the classification ability of a number of clinical variables and variables related to conformity to gender norms when determining whether or not women were receiving psychological care. Therefore, in order to make a classification model, two approaches were taken: a binary logistic regression model and a random forest model. After constructing the binary logistic regression model, the collinearity analysis concluded that more than $20 \%$ of the variables had a high degree of collinearity. The results of the logistic regression analysis and the adjustment of assumptions, including the analysis of collinearity between predictor variables, is available upon request from the lead author.

In view of their collinearity, a random forest classification model was considered (Breiman, 2001). This type of model makes it possible to work with variables exhibiting collinearity problems, among others. The 10-fold crossvalidation procedure was followed (Kuhn \& Johnson, 2013). It consists of a resampling method based on cross-validation in which the total sample is divided into 10 parts with approximately the same number of participants. A model is built using all but the first sample. The remaining sample is used to estimate the performance measures of the model. Hyperparameters of a random forest model include the number of trees (in this case, this value was set to 500) and the number of predictor variables in each tree (in this case, the optimal model allowed this value to be set to 18). The Gini indicator (Mean Decrease Gini) was used to assess the significance of the variables. The error rate was studied using out-of-bag (OOB) procedures. Model accuracy and concordance between trees were also studied. As this is a classification problem, this algorithm provides a confusion matrix from which the indicators of prevalence, sensitivity, specificity, diagnostic accuracy, diagnostic odds ratio, Youden index, positive predictive value, and negative predictive value can be derived. All these indicators are reported with a 95\% confidence interval.

Statistical analyses were performed using $\mathrm{R}$ software ( $\mathrm{R}$ Core Team, 2019), and the caret (Kuhn, 2020), psych (Revelle, 2019), ggplot2 (Wickham, 2016) and epiR (Stevenson, 2020) packages.

\section{Results}

The descriptive statistics for each of the predictor variables in each group, as well as the internal consistency coefficients for each of the scales, are shown in Table 3. The internal consistency of most of the scales is adequate, with the exception of the Antisocial scale of the PAI.

Table 3

Descriptive statistics for each of the variables in the present study.

\begin{tabular}{|c|c|c|c|c|c|c|c|c|}
\hline Scale & Variables & $a$ & $\omega$ & Group & Mean & SD & Minimun & Maximum \\
\hline \multirow{26}{*}{ PAI } & \multirow{2}{*}{ Somatic Concerns } & \multirow{2}{*}{.793} & \multirow{2}{*}{.822} & Clinical & 45.98 & 7.86 & 36.00 & 73.00 \\
\hline & & & & Non-clinical & 48.03 & 7.23 & 37.00 & 78.00 \\
\hline & \multirow{2}{*}{ Anxiety } & \multirow{2}{*}{.905} & \multirow{2}{*}{.909} & Clinical & 48.03 & 10.68 & 33.00 & 81.00 \\
\hline & & & & Non-clinical & 46.43 & 8.08 & 35.00 & 88.00 \\
\hline & \multirow{2}{*}{ Anxiety-Related Disorders } & \multirow{2}{*}{.846} & \multirow{2}{*}{.854} & Clinical & 49.62 & 10.78 & 29.00 & 78.00 \\
\hline & & & & Non-clinical & 48.42 & 9.19 & 34.00 & 87.00 \\
\hline & \multirow{2}{*}{ Depression } & \multirow{2}{*}{.865} & \multirow{2}{*}{.885} & Clinical & 48.26 & 10.96 & 35.00 & 90.00 \\
\hline & & & & Non-clinical & 48.83 & 9.19 & 39.00 & 99.00 \\
\hline & \multirow{2}{*}{ Mania } & \multirow{2}{*}{.747} & \multirow{2}{*}{.756} & Clinical & 48.36 & 9.63 & 32.00 & 84.00 \\
\hline & & & & Non-clinical & 45.97 & 8.68 & 33.00 & 77.00 \\
\hline & \multirow{2}{*}{ Paranoia } & \multirow{2}{*}{.828} & \multirow{2}{*}{.838} & Clinical & 47.02 & 9.26 & 30.00 & 74.00 \\
\hline & & & & Non-clinical & 47.80 & 9.11 & 31.00 & 86.00 \\
\hline & \multirow{2}{*}{ Schizophrenia } & \multirow{2}{*}{.817} & \multirow{2}{*}{.820} & Clinical & 47.29 & 9.76 & 35.00 & 81.00 \\
\hline & & & & Non-clinical & 45.68 & 8.45 & 35.00 & 87.00 \\
\hline & \multirow{2}{*}{ Borderline Features } & \multirow{2}{*}{.849} & \multirow{2}{*}{.852} & Clinical & 49.09 & 10.41 & 31.00 & 79.00 \\
\hline & & & & Non-clinical & 45.32 & 8.14 & 8.00 & 74.00 \\
\hline & \multirow{2}{*}{ Antisocial Features } & \multirow{2}{*}{.594} & \multirow{2}{*}{.646} & Clinical & 44.93 & 6.28 & 39.00 & 74.00 \\
\hline & & & & Non-clinical & 44.93 & 6.11 & 39.00 & 67.00 \\
\hline & \multirow{2}{*}{ Aggression } & \multirow{2}{*}{.732} & \multirow{2}{*}{.760} & Clinical & 49.29 & 9.06 & 36.00 & 82.00 \\
\hline & & & & Non-clinical & 47.92 & 6.89 & 37.00 & 80.00 \\
\hline & Sulcidlal Idention & 883 & 803 & Clinical & 48.33 & 11.57 & 42.00 & 110.00 \\
\hline & 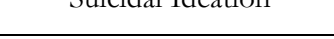 & .005 & .093 & Non-clinical & 48.44 & 7.66 & 42.00 & 110.00 \\
\hline & Stress & 673 & 704 & Clinical & 48.04 & 9.31 & 36.00 & 76.00 \\
\hline & stress & .075 & .104 & Non-clinical & 46.81 & 8.94 & 36.00 & 92.00 \\
\hline & Nonsunnort & 762 & 764 & Clinical & 48.17 & 9.18 & 35.00 & 77.00 \\
\hline & Nonsupport & .102 & .104 & Non-clinical & 50.51 & 9.80 & 36.00 & 82.00 \\
\hline
\end{tabular}




\begin{tabular}{|c|c|c|c|c|c|c|c|c|}
\hline Scale & Variables & $a$ & $\omega$ & Group & Mean & SD & Minimun & Maximum \\
\hline & & & & Clinical & 51.24 & 10.33 & 28.00 & 75.00 \\
\hline & Dominance & .100 & 1.50 & Non-clinical & 48.53 & 9.04 & 31.00 & 73.00 \\
\hline & 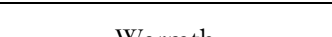 & 622 & 610 & Clinical & 50.18 & 9.75 & 22.00 & 68.00 \\
\hline & Warmth & .033 & .042 & Non-clinical & 50.68 & 8.79 & 26.00 & 67.00 \\
\hline \multirow{16}{*}{ CFNI } & \multirow{2}{*}{ Nice in Relationships } & \multirow{2}{*}{.735} & \multirow{2}{*}{.751} & Clinical & 50.16 & 11.06 & 12.19 & 80.06 \\
\hline & & & & Non-clinical & 49.89 & 9.04 & 26.87 & 76.39 \\
\hline & \multirow{2}{*}{ Care for Children } & \multirow{2}{*}{.914} & \multirow{2}{*}{.918} & Clinical & 48.21 & 10.32 & 20.63 & 71.74 \\
\hline & & & & Non-clinical & 51.57 & 9.48 & 20.63 & 70.30 \\
\hline & \multirow{2}{*}{ Thinness } & \multirow{2}{*}{.874} & \multirow{2}{*}{.874} & Clinical & 50.10 & 10.87 & 26.14 & 73.81 \\
\hline & & & & Non-clinical & 49.93 & 9.24 & 26.14 & 73.81 \\
\hline & \multirow{2}{*}{ Sexual Fidelity } & \multirow{2}{*}{.829} & \multirow{2}{*}{.829} & Clinical & 48.38 & 9.86 & 25.16 & 73.23 \\
\hline & & & & Non-clinical & 51.35 & 9.95 & 23.24 & 77.08 \\
\hline & \multirow{2}{*}{ Modesty } & \multirow{2}{*}{.754} & \multirow{2}{*}{.767} & Clinical & 49.57 & 10.85 & 21.84 & 86.64 \\
\hline & & & & Non-clinical & 50.35 & 9.25 & 21.84 & 86.64 \\
\hline & \multirow{2}{*}{ Romantic Relationship } & \multirow{2}{*}{.745} & \multirow{2}{*}{.755} & Clinical & 50.19 & 10.54 & 18.90 & 78.74 \\
\hline & & & & Non-clinical & 49.86 & 9.55 & 21.39 & 76.24 \\
\hline & \multirow{2}{*}{ Domestic } & \multirow{2}{*}{.773} & \multirow{2}{*}{.792} & Clinical & 48.26 & 10.03 & 21.03 & 71.35 \\
\hline & & & & Non-clinical & 51.48 & 9.78 & 26.62 & 71.35 \\
\hline & 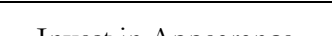 & 711 & 702 & Clinical & 48.83 & 10.30 & 22.53 & 73.45 \\
\hline & Invest in Appearance &.$/ 11$ & .122 & Non-clinical & 51.07 & 9.63 & 25.53 & 76.44 \\
\hline & Winning & 838 & 839 & Clinical & 50.20 & 10.62 & 23.66 & 78.70 \\
\hline & Winning & .838 & .839 & Non-clinical & 49.83 & 9.49 & 25.95 & 92.47 \\
\hline & Fontionl Contul & $00 ?$ & 000 & Clinical & 50.77 & 10.84 & 25.50 & 85.82 \\
\hline & Emotional Control & .882 & .888 & Non-clinical & 49.31 & 9.22 & 25.50 & 79.99 \\
\hline & Ricl Toling o o s & 811 & 813 & Clinical & 49.81 & 10.12 & 20.94 & 77.79 \\
\hline & Kisk-1 aking & .811 & .813 & Non-clinical & 50.14 & 9.94 & 23.53 & 77.79 \\
\hline & Viglense & 710 & 725 & Clinical & 51.52 & 10.52 & 34.43 & 89.37 \\
\hline & Violence &.$/ 10$ & .125 & Non-clinical & 48.70 & 9.39 & 34.43 & 75.64 \\
\hline & Power over Women & 625 & 692 & Clinical & 49.87 & 9.89 & 28.08 & 75.17 \\
\hline & Power over Women & .023 & .092 & Non-clinical & 50.10 & 10.14 & 28.02 & 79.10 \\
\hline$C M N I$ & & 714 & 723 & Clinical & 50.87 & 10.11 & 27.37 & 71.55 \\
\hline $\mathrm{CMNI}$ & Dominance & .714 & .723 & Non-clinical & 49.27 & 9.90 & 27.37 & 81.36 \\
\hline & Plarborr & 824 & 831 & Clinical & 50.07 & 10.24 & 29.62 & 87.01 \\
\hline & Playboy & .824 & .831 & Non-clinical & 49.95 & 9.84 & 27.70 & 85.10 \\
\hline & 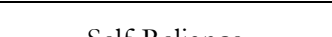 & 075 & 077 & Clinical & 51.55 & 11.04 & 32.43 & 82.41 \\
\hline & Selt-Reliance & $.8 / 5$ & .877 & Non-clinical & 48.62 & 8.83 & 32.43 & 82.41 \\
\hline & Primacy of Work & 757 & 760 & Clinical & 50.00 & 10.85 & 26.26 & 76.39 \\
\hline & Primacy of Work & $.15 /$ & .109 & Non-clinical & 49.99 & 9.26 & 26.26 & 85.79 \\
\hline & Dindain fo Ulomerulo & $00 ?$ & 007 & Clinical & 49.79 & 9.38 & 34.51 & 87.38 \\
\hline & Disdain for Homosexuals & .882 & $.88 /$ & Non-clinical & 50.20 & 10.55 & 34.51 & 91.44 \\
\hline & Durcuit of Statuc & 661 & 677 & Clinical & 49.89 & 11.00 & 19.88 & 75.97 \\
\hline & Pursuit of Status & .001 & $.0 / 1$ & Non-clinical & 50.10 & 9.11 & 27.89 & 79.98 \\
\hline$\Gamma \mathrm{CT}$ & 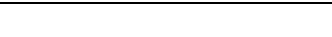 & 006 & 004 & Clinical & 51.13 & 11.19 & 34.57 & 86.81 \\
\hline EI & - & .070 & .904 & Non-clinical & 49.13 & 8.75 & 33.38 & 83.24 \\
\hline
\end{tabular}

Note. Data are expressed as T-scores: T=50+10·Z. $a$ : Cronbach's alpha. $\omega$ : McDonald's omega. SD: Standard deviation.

Random forest was the classifier algorithm used, constructed with 35 predictors and hyperparameters described in the Data Analysis section. The accuracy of the model obtained was $89.40 \%$ and the agreement between the trees was $x=0.787$. The confusion matrix is shown in Table 4. The OOB error was $12.01 \%$.

The importance of the variables is shown in Table 5. The most important variables belong to the PAI, with Suicidal Ideation being the most relevant scale, followed by Borderline Features, Somatic Concerns, Anxiety, Stress, Depression, and Anxiety-Related Disorders. Regarding gender, the
Table 4

Confusion matrix.

\begin{tabular}{lcccc}
\hline & & \multicolumn{2}{c}{ Random Forest Classification } & \multirow{2}{*}{ Total } \\
\cline { 3 - 4 } & & Clinical & Non-clinical & \\
\hline \multirow{2}{*}{ Group } & Clinical & 146 & 22 & 168 \\
& Non-clinical & 21 & 169 & 190 \\
\hline Total & 167 & 191 & \\
\hline Classification Error & 0.111 & 0.131 & \\
\hline
\end{tabular}

Sexual Fidelity, Care for Children, and Nice in Relationships scales had the highest classification ability, although far 
from the classification ability exhibited by the clinical scales. In the case of variables related to Conformity to Masculine Norms, they have little importance within the model, with the Power over Women and Self-Reliance scales attaining the highest values.

Table 5

Importance of each predictor variable.

\begin{tabular}{|c|c|c|c|c|c|}
\hline Clinical variables & Importance & $\mathrm{CMNI}$ & Importance & CFNI & Importance \\
\hline Suicidal Ideation & 104.90 & Pursuit of Status & 1.889 & Sexual fidelity & 3.181 \\
\hline Borderline Features & 12.767 & Winning & 1.672 & Care for Children & 4.089 \\
\hline Stress & 3.16 & Playboy & 1.639 & & \\
\hline Warmth & 3.084 & Self-Reliance & 1.637 & Nice in relationships & 3.764 \\
\hline Somatic Concerns & 2.310 & Power Over Women & 1.567 & Domestic & 1.174 \\
\hline Aggression & 2.834 & Primacy of Work & 1.425 & Thinness & 1.162 \\
\hline Anxiety & 2.688 & Violence & 1.309 & Invest in appearance & 1.120 \\
\hline Anxiety-Related Disorders & 2.500 & Risk-Taking & 1.149 & Modesty & 0.677 \\
\hline EAT* & 1.862 & Emotional Control & 1.081 & Romantic relationship & 0.750 \\
\hline Schizophrenia & 1.760 & Disdain for Homosexuals & 0.757 & & \\
\hline Nonsupport & 1.699 & Dominance & 0.727 & & \\
\hline Mania & 1.667 & & & & \\
\hline Depression & 1.585 & & & & \\
\hline Antisocial Features & 1.489 & & & & \\
\hline Dominance & 1.304 & & & & \\
\hline Paranoia & 1.286 & & & & \\
\hline
\end{tabular}

Note. The EAT score does not belong to the PAI.

Since the random forest algorithm has been used for classification, it was possible to obtain additional indicators of the quality of the model (see Table 6). The model has shown very good classification ability, as all diagnostic indicators have very high values.

Table 6

Additional indicators of classification ability.

\begin{tabular}{lccc}
\hline \multirow{2}{*}{ Indicator } & Estimation & $\begin{array}{r}\text { Lower } \\
\text { bound }\end{array}$ & $\begin{array}{c}\text { Upper } \\
\text { bound }\end{array}$ \\
\hline Prevalence & & .42 & .52 \\
Sensitivity & .47 & .84 & .94 \\
Specificity & .90 & .82 & .91 \\
Accuracy in diagnosis & .87 & .84 & .91 \\
Diagnostic Odds Ratio & .88 & 30.67 & 115.03 \\
Youden's Index & 59.39 & .66 & .85 \\
Positive predictive value & .77 & .78 & .90 \\
Negative predictive value & .85 & .87 & .95 \\
\hline
\end{tabular}

\section{Discussion}

The aim of this study was to explore the classification ability of a number of clinical variables and sociocultural factors related to conformity to gender norms in order to ascertain whether or not women were receiving psychological care and determine the importance of each of the variables when predicting which women were receiving therapy.

In this sample, the main reasons for consultation in the clinical group were related to anxiety problems (39.29\%) and depression $(27.38 \%$ ), which are among the most prevalent diagnoses in women (Bekker \& van Mens-Verhulst, 2007; Ferrari et al., 2013; Leal, 2006; Pérez \& Serra, 1997; Pérez \& Gaviña, 2015; Sáenz-Herrero, 2015; Salk et al., 2017; Sánchez-López \& Cuéllar, 2013), as well as couple relation- ship problems $(27.98 \%)$. The second most prevalent reason for consultation in the sample was couple relationship problems, which is not a clinical diagnosis in itself, but rather a concern frequently voiced by women in the clinical sample (women who were receiving psychotherapy). This is consistent with Velasco (2009), who reports that couple's conflicts were the psychosocial process most frequently associated with common mental disorders, somatisation, and pain among men and young women up to 44 years of age ( $p$. 181).

The data obtained indicate that women scoring higher on the clinical variables Suicidal Ideation (the variable with the highest weighting) and Borderline Features are more likely to be receiving psychological care. The present sample did not report significantly severe symptoms (women in the clinical sample were seen in private practices and not in hospitals), so a high score on this scale was indicative of severity, which fits with seeking therapy. Something similar could be said with respect to the Borderline Features variable, which is related to severe symptoms and an indicator of a higher likelihood of receiving psychological care. This is consistent with the fact that borderline personality disorder has a higher prevalence rate in women than in men (3:1) (Escribano, 2006; García et al., 2010; Kienast et al., 2014; Ortiz-Tallo et al., 2011; Skodol \& Bernder, 2003; Tomko et al., 2014; Trull et al., 2010).

The variables with the highest classification ability in determining whether a woman is receiving psychological care are typically associated with conformity to feminine gender roles: Care for Children, Nice in Relationships, and Sexual Fidelity. This is consistent with a number of studies suggesting that having feminine but also masculine traits (androgyny) was associated with less severe eating disorders and with 
the fact that femininity and anxiety are positively correlated, while masculinity and anxiety are negatively correlated (Hartung \& Lefler, 2019). In fact, one of the possible reasons why women have a higher prevalence of mental disorders than men is that social roles are different for each sex: moving away from gender ideals can be stressful for both women and men (if gender ideals are not met, it is more difficult to have a good external representation of self-worth). However, this has more negative consequences for women than for men (Matud \& Aguilera, 2009), as social norms and standards are known to guide and constrain behaviours (Cialdini \& Trost, 1999).

The clinical variables Stress, Warmth, Aggression, Anxiety, Anxiety-Related Disorders, and Somatic Concerns have the highest classification ability. These variables are related to the fact that women have a higher prevalence of internalising disorders (Eaton et al., 2012) and higher levels of social stress: they have a lower economic status and experience more abuse (sexual abuse and sexist violence) than men during both childhood and adulthood (WHO, 2018b). This is also consistent with some of the results found: women with higher femininity scores also had higher levels of anxiety and, overall, feminine traits hinder women's psychological wellbeing, as they are related to passivity, dependence, lack of assertiveness, and low self-esteem, which in turn are linked to anxious and depressive symptoms (Pérez \& Serra, 1997).

In terms of conformity to masculine gender norms, the variable Pursuit of Status is ranked first, followed closely by the clinical variable Eating Disorders. Being female and scoring high on a "typically masculine" (gender) variable makes that woman almost as likely to seek psychological help as when scoring high on the clinical variable Eating Disorders. Eating disorders are the most commonly diagnosed disorders among the young population (Sáenz-Herrero et al., 2015). However, in this study the Eating Disorders variable does not seem to be the most important variable when classifying the clinical population, which may be due to the fact that the mean age of the participants was 40 years old. Therefore, it may be argued that gender determinants are at the root of attitudes and lifestyles related to vulnerability and the tendency to become ill. For instance, the ideal of femininity based on a thin, inert body (the contemporary gender model) increases the vulnerability of young women whose identity is developing, leading to eating disorders (Velasco, 2009, p. 148). As Sánchez-López and Dresch (2012) state, "conformity to some feminine norms could be related to greater reporting of chronic illnesses, which is a health cost" (p. 192) and so "identifying the association between people's constructions of femininity and masculinity and their health may contribute to changing problematic constructions of gender norms using cognitive techniques” (p. 193).

\section{Conclusions}

We can conclude that gender variables have been found to be relevant in determining whether women are receiving psychological care, i.e. greater conformity to gender roles leads women to seek more psychological care. When studying health, it is essential to include not only sex as a variable, but also gender as a sociocultural dimension mediating illness. Our results show the importance of further exploring sex and gender as two different dimensions that need to be considered in research; otherwise, there is a risk of introducing bias into the study of health.

The inclusion of a gender perspective in research will help to achieve a broader understanding of the aetiology of disorders, i.e. the underlying reasons why men and women become ill differently, a phenomenon that is not sufficiently explained by biology. Being able to analyse the weight of sociocultural variables in the development of a given mental illness becomes crucial in order to identify the relevant factors of an illness. Integrating the gender perspective into educational and health-related programmes, clinical treatments (including individual psychotherapy), and prevention programmes may thus increase their effectiveness and efficiency.

Moving away from gender ideals can be stressful for both women and men (Matud \& Aguilera, 2009). However, not fitting into these ideals might not be so problematic if women were more aware of them and if they were to change. Taking a gender perspective approach and pointing to sociocultural factors as determinants, with the implications that this entails, can help to 'depsychopathologise' disorders experienced by women and to design interventions promoting healthier behaviours.

It is our belief that our findings provide an avenue worth exploring. However, our study has a number of limitations that should be considered. This study is the first part of a larger study that is projected to include men in the sample. A comparison of the scales between the sample of men and women could thus be made to explore models such as this one and study the health of women, men, and non-binary people. It would also have been interesting to include in the sample women with severe mental disorders, in institutional care, or with a non-university level of education in order to make the results more generalisable.

It is essential that future lines of research further explore the different forms of illness that men and women (as well as transgender people) experience by taking a feminist, biopsychosocial perspective and by defining more clearly the sex/gender constructs. This will result in better psychological care and better mental and overall health for women, men, and non-binary people. 


\section{References}

American Psychiatric Association. (2013). Diagnostic and statistical manual of mental disorders (5th ed.). American Psychiatric Association.

Arnett., A. B., Pennington, B. F., Willcutt, E. G., DeFries, J. C. \& Olson, R. K. (2015). Sex differences in ADHD Symptom Severity. Journal of child psychology and psychiatry, and allied disciplines, 56(6), 632-639. https://doi.org/10.1111/jicpp.12337

Bahamón, M. J., Alarcón-Vasquez, Y., Trejos-Herrera, A. M., Vinaccia, S., Cabezas, A. \& Sepúlveda-Aravena, J. (2019). Efectos del programa CIPRES sobre el riesgo de suicidio en adolescentes. Revista de Psicopatología y Psicología Clínica, 24(2), 93-91. https://doi.org/10.5944/rppc.23667

Baron-Cohen, S., Lombardo, M. V., Auyeung, B., Ashwin, E., Chakrabarti, B. \& Knickmeyer, R. (2011). Why are autism spectrum conditions more prevalent in males? PloS Biology, 9(6), e1001081. https://doi.org/10.1371/journal.pbio.1001081

Belle, D. \& Doucet, J. (2003). Poverty, inequality, and discrimination as sources of depression among U.S. women. Psychology of Women Quarterly, 27, 1-12. https://doi.org/10.1111/1471-6402.00090

Bekker, M. H., \& van Mens-Verhulst, J. (2007). Anxiety disorders: sex differences in prevalence, degree, and background, but gender-neutral treatment. Gender medicine, 4(B), S178-S193. https://doi.org/10.1016/s1550-8579(07)80057-x

Bott, N. T., Radke, A. E. \& Kiely, T. (2016). Ethical issues surrounding psychologists' use of neuroscience in the promotion and practice of psychotherapy. Professional Psychology: Research and Practice, 47(5), 312-329. https://doi.org/10.1037/pro0000103

Breiman, L. (2001). Random Forests. Machine Learning, 45, 5-32.

Case, A. \& Paxson, C. (2005). Sex differences in morbidity and mortality. Demography 42(2), 189-214. http://doi.org/10.2307/4147343

Chiasson, H. A., \& Hirsch,B. K. (2005). Women have worse long-term outcomes after coronary artery bypass grafting than men. The Canadian Journal of Cardiology, 21(9), 757-762.

Cialdini, R. B., \& Trost, M. R. (1999). Social influence: social norms, conformity, and compliance. En D. Gilbert, S. Fiske, \& G. Lindzy (Eds.), The handbook of social psychology (Vol. 2, pp. 151-192). McGraw-Hill.

Crimmins, E. M., Kim, J. K. \& Solé-Auró, A. (2010). Gender differences in health: results from SHARE, ELSA and HRS. European Journal of Public Health, 21(1), 81-91. https://doi.org/10.1093/eurpub/ckq022

Cuéllar-Flores, I., Sánchez-López, M. P. \& Dresch, V. (2011). El Inventario de Conformidad con las Normas de Género Masculinas (CMNI) en la población española. Anales de Psicología, 27(1), 170-178.

Dohrenwend, B. \& Dohrenwend, B. S. (1977). Sex differences in mental illness: a reply to Gove and Tudor. American Journal of Sociology, 82, 133641.

Eaton, N. R., Keyes, K. M., Krueger, R. F., Balsis, S., Skodol, A. E., Markon, K. E. \& Hasin, D. S. (2012). An invariant dimensional liability model of gender differences in mental disorder prevalence: Evidence from a national sample. Journal of Abnormal Psychology, 121, 282-288. https://doi.org/10.1037/a0024780

Ellis, L., Hershberger, S., Field, E., Wersinger, S., Pellis, S., Geary, D., Palmer, C., Hoyenga, K., Hetsroni, A. \& Karadi, K. (2008). Sex differences: Summarizing more than a century of scientific research. Psychology Press. https://doi.org/10.1007/s10508-009-9538-y

Engel, G. L. (1980). The clinical application of the biopsychosocial model. American Journal of Psychiatry, 137(5), 535-544. https://doi.org/10.1176/ajp.137.5.535

Escribano, T. (2006). Trastorno Límite de la Personalidad: Estudio y tratamiento. Intelligo, 1(1), 4-20.

Fernández, J. (2004). Perspectiva evolutiva: Identidades y desarrollos de comportamientos según el género. En Barberá, E. y Martínez, I. (Comp.), Psicología y género (pp. 35-53). Pearson.

Ferrari, A. J., Somerville, A. J., Baxter, A. J., Norman, R., Patten, S. B., Vos, T., \& Whiteford, H. A. (2013). Global variation in the prevalence and incidence of major depressive disorder: A systematic review of the epidemiological literature. Psychological Medicine, 43, 471-481. http://dx.doi.org/10.1017/S0033291712001511

Fine, C. (2018). Testosterona Rex. Mitos sobre sexo, ciencia y sociedad. Paidós.

Fletcher-Janzen, E. (Ed.). (2009). The neuropsychology of women. Springer.
Garandillas, A., Zorrilla, B. \& Sepúlveda, A. R. (2003). Trastornos del comportamiento alimentario: Prevalencia de casos clínicos en mujeres adolescentes en la Comunidad de Madrid. https://www.comunidad.madrid/servicios/salud

García, M. T., Martín, M. F. \& Otín, R. (2010). Tratamiento integral del trastorno de personalidad límite. Revista de la Asociación Española de Neuropsiquiatría, $\quad 30, \quad 263-278 . \quad$ https://doi.org/10.4321/S0211$\underline{57352010000200005}$

Garfinkel, P. \& Newman, A. (2001). The Eating Attitudes Test. Twenty-five years later. Eating and weight disorders, 6(1), 1-24. https://doi.org/10.1007/BF03339747

Garner, D. M., \& Garfinkel, P. E. (1979). The Eating Attitudes Test: An index of the symptoms of anorexia nervosa. Psychological Medicine, 9, 273279. https://doi.org/10.1017/s0033291700030762

Garner, D. M., Olmsted, M. P., Bohr, Y. \& Garfinkel, P. E. (1982). The Eating Attitudes Test: psychometric features and clinical correlates. Psychological Medicine, 12, 871-878. https://doi.org/10.1017/s0033291700049163

Garnica de Cos, E. (2015). Gender differences in personality disorders. En Sáenz-Herrero, M. (Ed.). Psychopathology in women. Incorporating gender perspective into descriptive psychopathology (pp. 527-559). Springer.

Giddens, A. \& Sutton, P. W. (2014). Sociología. Alianza Editorial.

Gove, W. (1984). Gender differences in mental and psychical illness: the effects of fixed roles and nurturant roles. Social science and medicine, 19(2), 77-91. https://doi.org/10.1016/0277-9536(84)90273-9

Hartung, C. M. \& Lefler, E. K. (2019). Sex and gender in psychopathology: DSM-5 and beyond. Psychollogical Bulletin, 145(4), 390-049. https://doi.org/10.1037/bul0000183

Jiménez, R. \& Vázquez, A. (2012). Esquizofrenia y género. Apuntes de Psicología, 30(1-3), 419-434.

Keel, P. K., \& Forney, K. J. (2013). Psychosocial risk factors for eating disorders. International Journal of Eating Disorders, 46, 433-439. http://dx.doi.org/10.1002/eat.22094

Kienast, T., Stoffers, J., Bermpohl, F. \& Lieb, K. (2014). Borderline personality disorder and comorbid addiction. Deutsches Äryteblatt International, 111(16), 280-286. https://doi.org/10.3238/arztebl.2014.0280

Kohen, D. (Ed.). (2010). Oxford textbook of women and mental health. Oxford University Press.

Kuhn, M. (2020). caret: Classification and Regression Training. R package version 6.0-85. https://CRAN.R-project.org/package $=$ caret.

Leal, C. (2006). Psicopatología y mujer: introducción. En J. Ezcurra, A. González-Pinto \& M. Gutiérrez-Pinto (Eds.), Psiquiatría y mujer (pp. 18). Aula Médica.

Mackenzie, C. S., Visperas, A., Ogrodniczuk, J. S., Oliffe, J. L. \& Nurmi, M. A. (2019). Age and sex differences in self-stigma and public stigma concerning depression and suicide in men. Stigma and Health, 4(2). https://doi.org/10.1037/sah0000138

Mahalik, J.R., Locke, B., Ludlow, L., Diemer, M., Scott, R.P.J. \& Gottfried, M. (2003). Development of the Conformity to Masculine Norms Inventory. Psychology of Men and Masculinity, 4(1), 3-25. https://doi.org/10.1037/1524-9220.4.1.3

Mahalik, J.R., Morray, E.B., Coonerty-Femiano, A., Ludlow, L.H., Slattery, S.M. \& Smiler, A. (2005). Development of the Conformity to Feminine Norms Inventory. Sex Roles, 52(7), 417-435. https://doi.org/10.1007/s11199-005-3709-7

Matud, M. P. \& Aguilera, L. (2009). Roles sexuales y salud mental en una muestra de la población española general. Salud Mental, 32, 53-58.

Meyer, L. \& Melchert, T. P. (2011). Examining the content of mental health intake assessments from a biopsychosocial perspective. Journal of Psychotherapy Integration, 21(1), 70-89. https://doi.org/10.1037/a0022907

Ministerio de Sanidad, Consumo y Bienestar Social [Spanish Ministry of Health, Consumer Affairs, and Social Welfare]. (2018a). Encuesta Nacional de Salud de España 2017. https://www.mscbs.gob.es/estadEstudios/estadisticas/encuestaNacio nal/home.htm

Ministerio de Sanidad, Consumo y Bienestar Social [Spanish Ministry of Health, Consumer Affairs, and Social Welfare]. (2018b). Encuesta Nacional de Salud de España 2017. Informe monográfico sobre salud mental. 
https://www.mscbs.gob.es/estadEstudios/estadisticas/encuestaNacio nal/encuestaNac2017/SALUD_MENTAL.pdf

Montero, I., Aparicio, D., Gómez-Beneyto, M., Moreno-Küstner, B., Reneses, B. \& Usall, J. (2004). Género y salud mental en un mundo cambiante. Gaceta Sanitaria, 18(1), 175-181. https://doi.org/10.1157/13062523

Morey, L. C. (2007). Personality Assessment Inventory: Professional manual (2nd ed.). Psychological Assessment Resources.

Nazroo, J. Y., Edwards, A. C. \& Brown, G. W. (2001). Gender differences in the prevalence of depression: artefact, alternative disorders, biology or roles? Sociology of Health and Illness, 20(3), 3112-330. https://doi.org/10.1111/1467-9566.00104

Oksuzyan, A., Danki, M. J., Caputo, J., Jasilionis, D. \& Shkolnikov, V. M. (2019). Is the story about sensitive women and stoical men true? Gender differences in health after adjustment for reporting behavior. Social Science \& Medicine, 228, 41-50. https://doi.org/10.1016/i.socscimed.2019.03.002

Ortiz-Tallo, M., Cardenal, V., Ferragut, M., \& Cerezo, M. V. (2011). Personalidad y síndromes clínicos: Un estudio con el MCMI-III basado en una muestra española. Revista de Psicopatología y Psicologia Clinica, 16(1), 49-59. https://doi.org/10.5944/rppc.vol.16.num.1.2011.10350

Ortiz-Tallo, M., Cardenal, V., Ferragut, M., \& Santamaría, P. (2015). Spanish and chilean standardizations of the personality assessment inventory: The influence of sex. The Spanish Journal of Psychology, 18, 1. https://doi.org/10.1017/spp.2015.57

Ortiz-Tallo, M., Santamaría, P., Cardenal, V. \& Sánchez-López, P. (2011). Inventario de Evaluación de la Personalidad PAI. Manuel de aplicación, corrección e interpretación. TEA Ediciones.

Pérez, P. \& Gaviña, J. (2015). Affective disorders. En Sáenz-Herrero, M. (Ed.), Psychopathology in women. Incorporating gender perspective into descriptive psychopathology (pp. 527-559). Springer.

Pérez, J. \& Serra, E. (1997). Influencia del rol tradicional femenino en la sintomatología ansiosa en una muestra de mujeres adultas. Anales de Psicologia, 13(2), 155-161.

Pike, K. M., Roberto, C., Wolk, S. L., Gluck, M. \& Walsh, B. T. (2008). Eating disorders measures. En A. J. Rush, M. B. First \& D. Blacker, D. (Eds.), Handbook of Psychiatric Measures (pp. 621-47). American Psychiatric Publishing.

R Core Team (2019). R: A language and environment for statistical computing. $\mathrm{R}$ Foundation for Statistical Computing, Vienna, Austria. URL https://www.R-project.org/.

Revelle, W. (2019) psych: Procedures for Personality and Psychological Research. Northwestern University, Evanston, Illinois, USA. https://CRAN.Rproject.org $/$ package $=$ psych Version $=1.9 .12$

Rivas, T., Bersabé, R., Jiménez, M. \& Berrocal, C. (2010). The Eating Attitudes Test (EAT-26): Reliability and Validity in Spanish Female Samples. The Spanish Journal of Psychology, 13(2), 1044-1056. https://doi.org/10.1017/S1138741600002687

Ruiz, P. M., Peláez-Fernández, M. A., Calvo, D., Pérez, J., Gómez, A. \& Calado, M. (2016). Diferencias por género de los trastornos de la conducta alimentaria en adolescentes españoles. Aequalitas, 39, 29-36.
Sáenz-Herrero, M. (Ed). (2015). Psychopatology in women. Incorporating gender perspective into descriptive psychopathology. Springer.

Salk, H., Hyde, J. \& Abramson, L. (2017). Gender differences in depression in representative national samples: Meta-analyses of diagnoses and $\begin{array}{lllll}\text { symptoms. } & \text { Psychological } & \text { Bulletin, } & 143(8), & 783-\end{array}$ 822. https://doi.org/10.1037/bul0000102

Sánchez-López, M. P. \& Cuéllar, I. (2013). Salud mental y género. En M. P. Sánchez-López (Coord.), La Salud de las Mujeres (pp. 189-213). Síntesis.

Sánchez-López, M. P., Cuéllar-Flores, I. \& Dresch, V. (2012). The impact of gender roles on health. Women \& Health, 52(2), 182-196. doi:10.1080/03630242.2011.652352

Sánchez-López, M. P., Cuéllar-Flores, I., Dresch, V. \& Aparicio-García, M. (2009). Conformity to feminine gender norms in the Spanish population. Social behavior and personality, 37(9), 1171-1186. https://doi.org/10.2224/sbp.2009.37.9.1171

Sánchez-López, P. \& Limiñana, R. (Ed.) (2017). The psychology of gender and health. Conceptual and applied global concerns. Elsevier.

Sánchez, T. (2018). Políticas sanitarias e igualdad entre mujeres y hombres. Revista de Bioética y Derecho, 43, 179-192.

Skodol, A. E. \& Bender, D. S. (2003). Why are women diagnosed borderline more than men? Psychiatric Quarterly, 74(4), 349-360. https://doi.org/10.1023/A:1026087410516

Stevenson, M. (2020). epiR: Tools for the Analysis of Epidemiological Data. R package version 1.0-11. https://CRAN.R-project.org/package=epiR.

Tomko, R. L., Trull, T. J., Wood, P. K., \& Sher, K. J. (2014). Characteristics of borderline personality disorder in a community sample: comorbidity, treatment utilization, and general functioning. Journal of personality disorders, 28(5), 734-750. https://doi.org/10.1521/pedi_2012_26_093

Trull, T. J., Jahng, S., Tomko, R. L., Wood, P. K. \& Sher, K. J. (2010). Revised NESARC personality disorder diagnoses: gender, prevalence, and comorbidity with substance dependence disorders. Journal of Personality Disorders, 24(4), 412-26. https://doi.org/10.1521/pedi.2010.24.4.412

Velasco, S. (2007). Evaluación de una intervención biopsicosocial para el malestar de las mujeres en atención primeria. Feminismo/s, 10, 111-131.

Velasco, S. (2009). Sexo, género y salud. Teoría y métodos para la práctica clínica y programas de salud. Minerva Ediciones.

Wickham, H. (2016). goplot2: Elegant Graphics for Data Analysis. Springer.

Wood, W. \& Eagly, A. (2013). Biology or culture alone cannot account for human sex differences and similarities. Psychological Inquiry, 24(3), 241247. https://doi.org/10.1080/1047840X.2013.815034

World Health Organisation (2018a). Salud de la mujer. Datos y cifras. https://www.who.int/es/news-room/fact-sheets/detail/women-shealth

World Health Organisation (2018b). Género y salud. Datos y cifras. https://www.who.int/es/news-room/fact-sheets/detail/gender

World Health Organisation (2019). Género y salud. https://www.who.int/es/news-room/fact-sheets/detail/gender

Yagahmaian, R. \& Miller Smedema, S. (2019). A feminist, biopsychosocia subjective well-being framework for women with fibromyalgia. Rebabili tation Psychology, 64(2), 154-166. https://doi.org/10.1037/rep0000226 